\title{
Military expenditure and foreign aid: should they be linked?
}

\author{
Anthony B Zwi, Antonio Ugalde
}

World military expenditure on the scale that has occurred in the past two decades has had a detrimental effect on global security and a weakening effect on social sector expenditure in many countries.

Worldwide, nearly $\$ 950$ billion is spent annually on the military; the former East-West confrontation in Europe still consumes nearly two thirds of this sum. ${ }^{1}$ Military expenditure by developing countries has increased more than fivefold in constant US dollars (far faster than in the industrialised countries), while the gross national product per head has less than doubled. ${ }^{2}$ The rate of increase in military expenditure has greatly exceeded the rate of increase in development aid to the Third World.

\section{Possible dividends of peace}

The United Nations Development Programme has argued that a $3 \%$ cut in military expenditure by developing countries could release $\$ 25$ billion a year for development activities. A freeze in current military expenditure in developing countries would save potential increases of $\$ 10$ billion a year, providing opportunities for alternative investments. ${ }^{3}$ Others believe a far larger peace dividend - of the order of $\$ 100$ billion a year-is possible. This towers over estimates from Unicef that $\$ 2.5$ billion a year would be needed to prevent child mortality and malnutrition for 50 million children; that $\$ 1$ billion annually will be required for the World Health Organisation's global "Health for All" programme; and that about $\$ 5$ billion would be needed to ensure that every child has access to primary school by the end of this decade. ${ }^{1}$

The resources consumed in weapons production, distribution, and utilisation could be used more productively. Military expenditure produces fewer jobs than the same amount invested in manufacturing or the social sector. ${ }^{4}$ Massive resources are frequently required to reconstruct the physical, economic, and social infrastructure after violent conflicts. At least a quarter of Third World debt results from military purchases. ${ }^{5}$

\section{Health Policy Unit, Department of Public Health and Policy, London School of Hygiene and Tropical Medicine, London WC1E 7HT Anthony B Zwi, lecturer in epidemiology and health policy}

University of Texas at Austin, Austin, Texas, USA

Antonio Ugalde, professor of sociology

Correspondence to: Dr Zwi.

BMF 1992;304:1421-2

\section{Quality of government and human rights}

Both militarism (an increasing propensity by states and significant groups within states to rely on force as a political tactic) and militarisation (an increase in armaments and people carrying weapons as well as advances in the destructive capability of weapons) pose problems. ${ }^{6}$ Military governments tend to have poorer human rights records and to inflict repression on their communities more readily and have generally failed to devote adequate attention to the complex problems of development. Violence and repression become the routine means of resolving international and intramilitary regime which has contributed to improvement in the quality of life of most of the people. Usually the opposite has ensued, policies of military governments leading to economic chaos, political instability, and national conflict. ${ }^{47}$ In Latin America there is no
- At least a quarter of Third World debt is due to military purchases

- Military expenditure has grown more than twice as fast as gross national product in developing countries

- A 3\% cut in Third World military expenditure would release $£ 25$ bn a year for development; $£ 5$ bn would ensure that every child has access to primary school education

- Much military expenditure has been encouraged by industrial countries, which are the main producers of weapons

- Half the United States' bilateral aid is allocated to the military and countries of geomilitary importance

- Reduction of military expenditure could be achieved by targeting money at social sectors, but directly linking aid to demilitarisation may doubly penalise the suffering population

deep social wounds. The very nature of military spending heightens tensions, reduces security, and underpins the system which makes even more arms necessary. ${ }^{8}$

Economic reforms have become important in securing international aid and loans. Considerations of "good government," human rights, and, recently, military expenditure have also been placed on the aid agenda. Lynda Chalker, British minister for overseas development, stated that the British government regards an "appropriate level" of military expenditure as a feature of good government (speech delivered at Royal Institute of International Affairs, London, June 1991). The UNDP argues that aid should cease when military expenditure exceeds spending on health and education. ${ }^{3}$ The International Monetary Fund and World Bank are considering these issues.

\section{Aid and reorientation of military expenditure}

With the cold war over, single party states on the retreat, trends towards democracy widespread, and peace on the agenda in many embattled regions the time is right to reflect on the potential for reorientating military expenditure. Reduced military expenditures would facilitate increased economic activities and allow foreign exchange to become available for other purposes, ${ }^{9}$ freeing personnel to work on more productive pursuits, and should actively be pursued. But other issues also need to be considered in determining whether development aid should be specifically linked to a nation's military expenditure patterns.

Since the second world war almost all wars have been fought in the Third World, and much of this military 


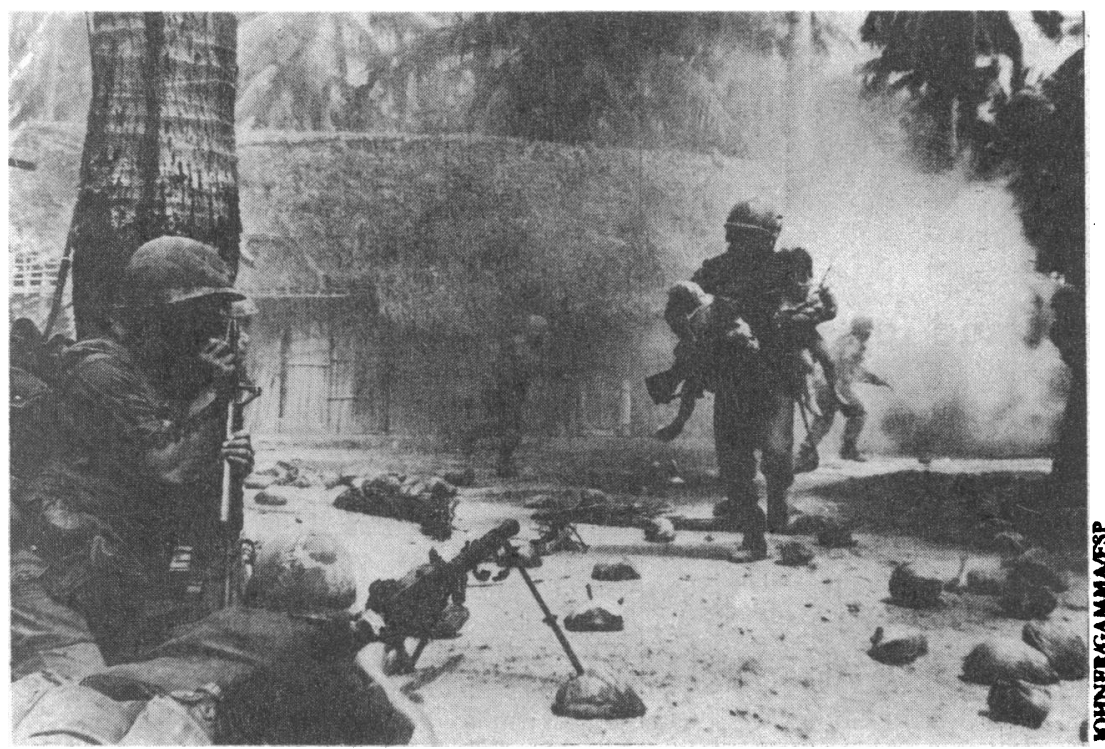

Wartorn Vietnam: Third World country suffering military conflict between superpowers

conflict has been stimulated by superpower rivalryfor example, in Vietnam, Angola, the Middle East, and Afghanistan. Hence penalising the countries involved for wars which were exacerbated by external factors is problematical.

Secondly, by far the biggest producers and exporters of weapons have been industrialised countries, which have benefited greatly from sales. These countries have also been closely concerned in providing aid for militarisation, training forces, and, in some areas, instigating coup d'états and military interventions. They have therefore had little incentive to promote reductions in military expenditure in the Third World or in their own countries. About half of the bilateral aid provided by the United States is allocated to the military, the vast majority to countries of geomilitary importance, such as Israel, Egypt, the Philippines, Pakistan, and Korea.

Thirdly, many countries, including the United States, have high military to social expenditure ratios. Although many are reducing their military expenditures, it is not suggested that this be dictated by external economic or political pressure; that would have significant impacts on sovereignty, which the targeted nations would resist. If the process of demilitarisation is to appear legitimate it should not be characterised by double standards.

Fourthly, in some cases the superpowers or their proxies have forced up military expenditure. Nicaragua increased military spending and diverted funds away from health and education programmes in order to counter the American supported Contras. Mozambique was similarly affected by insurgents backed by South Africa. ${ }^{10}$ Suspending aid once military expenditure exceeds a given proportion of the gross national product or government expenditure may encourage opponents to support armed opposition, forcing up military spending and triggering a decline in foreign aid, undermining the government in power.

Even multilateral humanitarian and food aid has been used selectively to support militarised regimes. Honduras, where the real holder of power during "civilian" regimes has been the military, received far more refugee assistance per head than Nicaragua, which has many more refugees and displaced persons.

Thus, although demilitarisation is a necessary and urgent objective, it cannot be imposed by force through linking economic aid with demilitarisation only in the Third World. The way forward is more complex. Suspending aid will not solve the underlying problems and may doubly penalise people already suffering under such regimes.

\section{More balanced policies for aid}

In order to achieve their objectives, policies aimed at reducing military expenditure and promoting social expenditure need to be more balanced. Rather than tying humanitarian assistance and foreign aid to a reduction in military expenditure, industrialised nations-and the world community-should support the following elements of an appropriate response.

In encouraging "good aid":

(1) Stimulate regional development, economic cooperation, and resolution of conflict.

(2) Confront social and economic inequities and correct the maldistribution of resources.

(3) Encourage accountable democratic government.

(4) Increase support for non-governmental organisations which promote participation, accountability, and democratic decision making structures.

(5) Facilitate internationally accepted guidelines for humanitarian aid, allowing non-governmental, multilateral agencies to give direct assistance to affected communities.

(6) Encourage countries $(a)$ to increase the amount of development aid from the currently low proportion of their gross national products $(0.15 \%$ and $0.31 \%$ respectively in the United States and United Kingdom in 1989) to fulfil the target of $0.7 \%$ of gross national product agreed by the international community, and (b) to increase the proportion of aid which is specifically directed at the social sector and human priority areas. These targets could easily be met by demilitarisation.

In tackling military expenditure:

(7) Encourage global military expenditure reductions.

(8) Create agreed targets for reductions in military expenditure and phased creation of global reductions in weapons deployment.

(9) Register, monitor, and publish details of all weapons sales.

(10) Strengthen and democratise the United Nations and its related structures, ensuring non-domination by a small clique or single superpower.

Movement towards more democratic government reflecting the interests of the majority of the people has to be won from below rather than imposed from above. The role of supportive donors, non-governmental organisations, and national governments should be to work towards achieving all, and not only some, of the above objectives.

We acknowledge the comments of numerous colleagues who saw an earlier version of this paper. $A B Z$ is a member of the Health Economics Financing Programme (funded by the Overseas Development Administration) at the London School of Hygiene and Tropical Medicine. The views reflected are ours alone.

1 Stockholm initiative on global security and governance. Common responsibility in the 1990s. Stockholm: Prime Minister's Office, 1991.

Galbraith JK. At the mercy of the military. Guandian 1991 Aug 6:17 (cols 1-6). 3 United Nations Development Programme. Human development report. Oxford: Oxford University Press, 1991.

Sivand RL. World military and sacial expenditures 1989.13 th ed. Washington DC: World Priorities 1989.

Tansey G. Real security. East, west, north and south. Londan: Wortd Development Movement. Eass,

6 Thee M. Mill ariem and In: Eide $A$, Thee $M$, eds. Prablems of contemporary militarism. London: Croom Helm, 1980.

7 Zwi A, Ugalde A. Political violence in the Third World: a public health issuc. Healsh Policy and Pleuning 1991;6:203-17.

8 Thorsson I. The ams race and development: a competitive relationship. Development 1982;1:12-5.

9 Looney RE. The policy relevance of recent research on the economics of Third World military expenditures. Fournal of Social, Political and Economic Studies 1990;15:213-23.

0 Cliff J, Noormahommed AR. Health as a target: South Africa's destabilisation of Mozambique. Soc Sci Med 1988;27:717-22.

(Accepted I April 1992) 